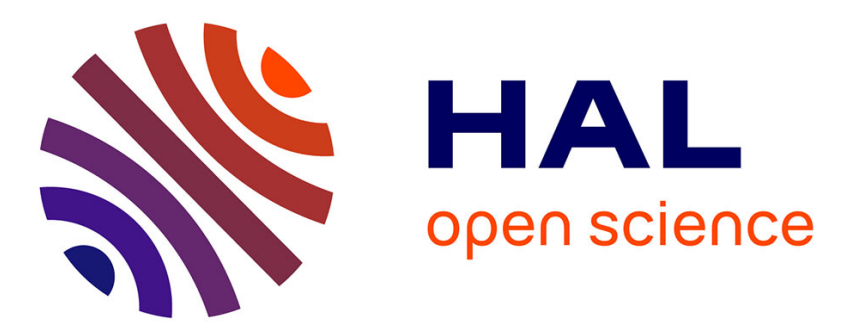

\title{
Control of pathogens and microbiota by innate lymphoid cells
}

Sascha Cording, Jasna Medvedovic, Emelyne Lecuyer, Tegest Aychek, Gerard Eberl

\section{- To cite this version:}

Sascha Cording, Jasna Medvedovic, Emelyne Lecuyer, Tegest Aychek, Gerard Eberl. Control of pathogens and microbiota by innate lymphoid cells. Microbes and Infection, 2018, 10.1016/j.micinf.2018.05.003 . pasteur-01824045

\section{HAL Id: pasteur-01824045}

https://hal-pasteur.archives-ouvertes.fr/pasteur-01824045

Submitted on 26 Jun 2018

HAL is a multi-disciplinary open access archive for the deposit and dissemination of scientific research documents, whether they are published or not. The documents may come from teaching and research institutions in France or abroad, or from public or private research centers.
L'archive ouverte pluridisciplinaire HAL, est destinée au dépôt et à la diffusion de documents scientifiques de niveau recherche, publiés ou non, émanant des établissements d'enseignement et de recherche français ou étrangers, des laboratoires publics ou privés.

\section{(ㅇ)(1) 80}

Distributed under a Creative Commons Attribution - NonCommercial - ShareAlikel 4.0 


\section{Accepted Manuscript}

Control of pathogens and microbiota by innate lymphoid cells

Sascha Cording, Jasna Medvedovic, Emelyne Lecuyer, Tegest Aychek, Gérard Eberl

Sascha Cording, Jasna Medvedovic, Emelyne Lecuyer, Tegest Aychek, Gerard Eberl

PII:

S1286-4579(18)30109-6

DOI:

10.1016/j.micinf.2018.05.003

Reference: MICINF 4587

To appear in: Microbes and Infection

Received Date: 5 April 2018

Accepted Date: 22 May 2018

Please cite this article as: S. Cording, J. Medvedovic, E. Lecuyer, T. Aychek, G. Eberl, Control of pathogens and microbiota by innate lymphoid cells, Microbes and Infection (2018), doi: 10.1016/ j.micinf.2018.05.003.

This is a PDF file of an unedited manuscript that has been accepted for publication. As a service to our customers we are providing this early version of the manuscript. The manuscript will undergo copyediting, typesetting, and review of the resulting proof before it is published in its final form. Please note that during the production process errors may be discovered which could affect the content, and all legal disclaimers that apply to the journal pertain. 


\section{Control of pathogens and microbiota by innate lymphoid cells}

2

3 Sascha Cording ${ }^{1,2,3}$, Jasna Medvedovic ${ }^{1,2}$, Emelyne Lecuyer ${ }^{1,2}$, Tegest Aychek ${ }^{1,2}$, Gérard 4 Eberl $^{1,2}$

5

$6 \quad{ }^{1}$ Institut Pasteur, Microenvironment \& Immunity Unit, 75724 Paris, France

$7 \quad{ }^{2}$ INSERM U1224, 75724 Paris, France

$8{ }^{3}$ Present address: INSERM, U989, Institut IMAGINE, and Université Paris Descartes-

9 Sorbonne Paris Cité, Paris, France

10

11 Corresponding author: Gérard Eberl

12 E-mail address: gerard.eberl@pasteur.fr

13

14 


\section{Summary}

16 Innate lymphoid cells (ILCs) are the innate counterpart of T cells. Upon infection or injury,

17 ILCs react promptly to direct the developing immune response to the one most adapted to the 18 threat facing the organism. Therefore, ILCs play an important role early in resistance to 19 infection, but also to maintain homeostasis with the symbiotic microbiota following 20 perturbations induced by diet and pathogens. Such roles of ILCs have been best characterized 21 in the intestine and lung, mucosal sites that are exposed to the environment and are therefore 22 colonized with diverse but specific types of microbes. Understanding the dialogue between 23 pathogens, microbiota and ILCs may lead to new strategies to re-inforce immunity for 24 prevention, vaccination and therapy.

26 Keywords: Innate lymphoid cells, microbiota, pathogens, homeostasis, mucosal immunity 27 


\section{Introduction}

ILCs derive from a lymphoid cell precursor common with $\mathrm{T}$ cells, with whom they share phenotypes and functions [1,2]. However, T cells are antigen-specific, carry immunological memory, and are selected by their cognate antigen in lymph nodes and Peyer's patches before expansion. Once activated, $\mathrm{T}$ cells recirculate through the blood to reach organs where their effector functions are required, eventually committing apoptosis or remaining in tissues as resident memory $\mathrm{T}\left(\mathrm{T}_{\mathrm{RM}}\right)$ cells [3]. Nevertheless, the process of $\mathrm{T}$ cell selection, activation and recirculation requires several days, leaving the early phase of the immune response without $\mathrm{T}$ cell-mediated orchestration of the response best adapted to the type of threat faced by the individual. However, early orchestration is directed by ILCs, which perform similar regulatory functions and provide prompt effector responses to infection and injury. ILCs also play important roles early in life, when the adaptive immune system is not yet in place [1].

An individual faced with intracellular threats, such as tumors, viruses and particular bacteria, responds with type 1 immune responses characterized by the production of type I interferons, the inducer cytokine IL-12, the effector cytokine IFN $\gamma$, the release of cytotoxic oxygen radicals and proteins, and the elimination of the transformed or infected cells (Figure 1). Extracellular microbes, such as bacteria and fungi, elicit type 3 responses that are characterized by the release of the inducer cytokine IL-23 and the production of the effector cytokines IL-17 and IL-22, which lead to the reinforcement of mucosal barriers and the recruitment of polymorphonuclear neutrophilic phagocytes that target, ingest and destroy the microbes. In contrast, when faced with large parasites, such as worms, the individual develops type 2 responses that lead to the release of fluids and the production of mucus at mucosal surfaces, and the deposition of collagen to resist parasite penetration. The type 2 inducer cytokines are IL-25, IL-33 and TSLP, which lead to the production of the effector cytokines IL-4, IL-5 and IL-13. Myeloid cells and stromal cells produce the appropriate inducer cytokines in response to a specific type of threat, activating ILCs and T cells to differentiate into ILC1s and Th1, ILC2s and Th2, or ILC3s and Th17, which produce the effector cytokines characteristic of type 1, 2 and 3 immunity [1,4].

Importantly, these immune responses are not only engaged in response to pathogens and tissue injury, but also in response to the symbiotic microbiota [5]. Microbes are present at all mucosal surfaces, as well as within tissues. An estimated $10^{14}$ bacteria reside in the intestine, together with viruses, fungi, protists and occasional worms, while smaller yet significant collections of microbes are present in the oral cavity, genitourinary system and skin [6,7]. Furthermore, the list of viruses found within our organism is expanding [8], and 
bacteria have been identified in lymphoid tissues [9,10] and placenta [11]. As a consequence, the immune system is constantly activated by the presence of these diverse symbiotic microbes. We have therefore argued that the primary function of the immune system is to maintain homeostasis of the host with its microbiota [5], a microbiota that is necessary for digestion, production of metabolites and defense. In contrast, if microbes are associated with injury of the host's cells and tissues, the immune reaction will lead to the elimination of the pathogens.

In this review, we discuss the role of ILCs in the control of the symbiotic or pathogenic microbiota (Figure 2 and Table 1). From recent data, it emerges that ILCs play unique roles in microbiota control, observations that may lead to a new understanding of how chronic inflammatory pathologies emerge when such control is lost, and create new opportunities for prevention and therapy of infectious diseases. We will not discuss the role of NK cells, the oldest member of the ILC family, which has been extensively studied since 40 years and best reviewed elsewhere [12].

\section{ILCs in the control of intestinal and hepatic infections}

ILC $3 \mathrm{~s}$ are the oldest and best characterized ILC family member (not considering NK cells). In the late 90's, non-B non-T lymphoid cells, termed lymphoid tissue inducer (LTi) cells, have been described that colonize developing secondary lymphoid tissues, the lymph nodes and the Peyer's patches, and shown to be required for their development [13,14]. LTi cells form clusters in fetal lymphoid tissues and the intestinal lamina propria [15], and activate stromal cells to initiate organogenesis [16]. Ten years later, it was shown that LTi cells are part of a larger family of ILC $3 \mathrm{~s}$ that depend on the hormone receptor and transcription factor ROR $\gamma \mathrm{t}$ [17], and express the type 3 cytokines IL-17, IL-22 and lymphotoxin (LT) [18-21]. Non-LTi ILC3s do not cluster and are not involved in the development of lymphoid tissues. Rather, these cells resemble more freely moving lymphoid effector cells, and together with LTi cells, play a critical role early in defense against enteric pathogens.

Using mouse models that lack all lymphoid cells or only B and T cells, it was reported that ILC3s are required early in the control of intestinal infection by Proteobacteria, such as Citrobacter rodentium, the murine homologue of human enteropathogenic Escherichia coli. The production of IL-22 is paramount for this protective function, and induces the expression of anti-microbial peptides (AMPs) by epithelial cells, such as $\operatorname{Reg} 3 \gamma$ [18,21-23]. Also involved in increasing epithelial defense is membrane-bound LT, which bind its receptor 
LT $\beta R$ on epithelial cells and induces expression of the neutrophils chemoattractants CXCL1 and CXCL2 [24]. Furthermore, ILC3s are involved in the response to infection by Salmonella enterica through the production of IL-17 and IL22, as well as IFN $\gamma$ [25]. The production of IL-17 by ILC3s and the recruitment of neutrophils are essential in the response to infection by E.coli K1 and Klebsiella pneumoniae and to prevent sepsis [26]. The protective role of ILC3s against pathogens extends to parasites and viruses. Infection by Toxoplasma gondii leads to more severe inflammatory pathology in the absence of ILC3s, presumably because of a failure to contain the parasites early [27]. Furthermore, IL-22 production by ILC3s potentiates the activity of IFN $\lambda$ in epithelial cells and thus increases resistance to rotavirus [28]. However, the pro-inflammatory activity of ILC3s may also lead to pathology through the production of IFN $\gamma$ in the context of S. enterica infection [25], as well as intestinal fibrosis through the expression of IL-17 and IL-22 in the context of S. typhimurium infection [29].

ILC2s were first reported in the context of intestinal infection with the helminth Nippostrongylus brasiliensis, which evokes a vigorous expansion of "non-B non-T cells" expressing IL-4, IL-5 an IL-13 [30,31]. ILC2 are also involved in defense against Heligmosomoides polygyrus [32], Strongyloides venezuelensis [33], Trichinella spiralis [34] and T. muris [35], and are diminished in the blood of children infected with the blood dweller Schistosoma haematobium [36]. Both inducer cytokines IL-25 and IL-33 are expressed upon helminth infection and activate ILC2s, noting that ILC2s responding to IL-33 have been suggested to be precursors of ILC2s responding to IL-25 [37]. While IL-33 is expressed by different types of stromal cells, as well as by mast cells [32], the source of IL-25 was only recently identified, in the intestine, as Tuft epithelial cells [38-40]. Interestingly, Tuft cells appear to detect helminth infection through chemosensory signaling via the G-protein coupled receptor Trpm5 [38]. The activity of ILC2s is also promoted, during helminth infection, by the neuropeptide neuromedin $U$ that is expressed by cholinergic neurons in the intestine $[41,42]$.

ILC1s are distinguished from NK cells by their lack of expression of, and requirement for, the transcription factor Eomesodermin [2]. ILC1s provide early protection to the liver from mouse cytomegalovirus infection, producing IFN $\gamma$ before NK cells are engaged [43], but at the same time prevent the recruitment of $\mathrm{NK}$ cells and $\mathrm{CD} 8^{+} \mathrm{T}$ cells that optimally fight liver infection with adenovirus [44]. Mouse hepatitis virus inoculated orally is also cleared from the intestine by ILC1s, which are activated by IL-15 released from infected stromal cells [45]. Futhermore, ILC1s and their production of IFN $\gamma$ are engaged in the defense against 
bacteria, such as Clostridium difficile [46]. Nevertheless, ILC1s and NK cells have largely

130 overlapping function, even though ILC1s are defined as non-cytotoxic. As both cells types react promptly to activators such as $\mathrm{IL}-12$, their relative role is mostly dependent on their tissue distribution before infection.

\section{The ILC crosstalk with intestinal microbiota}

The large intestinal microbiota has been best characterized, so far, at the level of its bacteriome and of its cross-talk between symbiotic bacteria and ILC3s. In contrast, the interaction between the virome and ILCs remains largely unexplored, and ILC2s are not known to cross-talk with microbes, even though some bacteria have been reported to induce the expansion of ILC2s at the steady state [47]. Therefore, this chapter will discuss mostly our knowledge on the cross-talk between bacterial symbionts and ILC3s.

In 2008, we reported that peptidoglycan released by proliferating Gram $^{-}$bacteria in the intestine induce the activation of LTi cells clustered in so-called cryptopatches [15], which are found near the base of crypts in the small intestine [48]. LTi cells in turn activate underlying stromal cells to release chemokines and recruit $\mathrm{CCR} 6^{+} \mathrm{B}$ cells to form isolated lymphoid follicles (ILFs). ILFs generate microbiota-specific IgA-producing B cells, in a T-cell independent way, and play an important role in intestinal homeostasis [15,49]. The colonizing microbiota is therefore involved in the development of the intestinal immune system. At the same time, it provides a negative feedback on the number and activity of ILC3s, which include LTi cells, by inducing epithelial cells to produce IL-25 [47]. Of note, in both these phenomena, epithelial cells translate the recognition of microbes into signals that regulate ILCs.

Myeloid cells are nevertheless the major relay between microbiota and ILC3s through the production of the type 3 inducer cytokines IL-23 and IL-1 $\beta$. In the context of $C$. rodentium infection, $\mathrm{CX}_{3} \mathrm{CR} 1^{+}$macrophages produce higher amounts of these cytokines than do conventional $\mathrm{CD} 103^{+} \mathrm{DCs}$, and thus, more efficiently induce the expression by ILC3s of IL-22 [50] and GM-CSF [51]. In addition, $\mathrm{CD} 11 \mathrm{~b}^{+}$DCs, which include $\mathrm{CX}_{3} \mathrm{CR}^{+}$cells, are obligate sources of IL-23 for host survival during C. rodentium infection [52], and TNF $\alpha$ produced by $\mathrm{CD}_{11 \mathrm{~b}^{+}}$DCs during Helicobacter typhlonius infection synergizes with IL-23 for the expression of IL-17 by ILC3s [53]. CD11 b ${ }^{+}$DCs are also activated by microbiota-derived ATP to produce IL-23 during the steady state [54]. Other members of the symbiotic microbiota induce the expression of IL-23 by myeloid cells and as a consequence, IL-22 by ILC3s, such as SFB [55] and Lactobacilli species [56]. ILC3s feedback positively on the 
production of IL-23 by myeloid cells through their expression of membrane-bound LT and activation of LT $\beta$ R on DCs [57]. Unexpectedly, intestinal glial cells sense microbiota through a Myd88-dependent pathway and produce neurotrophic factors that activate the Ret receptor on ILC3s and promote their expression of IL-22 [58].

At the steady state, ILC3s are the major source of IL-22 [47]. IL-22, as well as IL-17, induce the production of AMPs by epithelial cells [59], and therefore, are critical for the containment not only of pathogens, but also of the symbiotic microbiota. IL-22 also regulates the fucosylation of epithelial cells, a dietary carbohydrate for many symbionts, and thereby increases resistance to infection by Salmonella typhimurium [60] and C. rodentium [61]. Furthermore, membrane-bound $\left(\mathrm{LT} \alpha_{1} \beta_{2}\right)$ and soluble $\left(\mathrm{LT} \alpha_{3}\right)$ LT expressed by ILC3s play an important role in the containment of the microbiota [62] through the activation of epithelial cells [24], as well as of DCs and T cells that lead to the production of anti-microbial IgA [63].

The containment of microbiota through the enhancement of epithelial defenses and adaptive immunity must nevertheless be controlled to avoid exaggerate responses to the symbiotic microbiota and consequent pathologic inflammation. To this end, ILCs express MHC class II molecules, as well as the machinery required to process proteins for presentation of peptides onto class II molecules, allowing ILCs to dampen the $\mathrm{CD}^{+} \mathrm{T}$ cell response to microbiota [64] and to SFB in particular [65]. Reciprocally, the presence of $\mathrm{CD}^{+} \mathrm{T}$ cells in the intestinal lamina propria decreases the expression of IL-22 by ILC3s $[47,66]$, presumably through competition for survival and inducing cytokines such as IL-23.

Bacterial symbionts of the Alcaligenes genus have been identified that are present in Peyer's patches. ILC3s and IL-22 are critical for the containment of Alcaligenes, as the depletion of ILCs using an anti-CD90 antibody leads to the presence of the bacteria in spleen and liver [9]. The depletion experiments were performed in Rag-deficient mice, as well as in mice reconstituted with mature $\mathrm{B}$ and $\mathrm{T}$ cells, indicating that adaptive immunity is not necessary for the containment of Alcaligenes. It remains nevertheless possible that, in normal mice, adaptive immunity develops over time that contributes to the containment of these symbionts through the generation of antibodies. As a matter of fact, Alcaligenes promotes the generation of $\operatorname{IgA}$, which contribute to the construction of its niche [10].

\section{Microbe-ILC interactions in the lungs}

The impact of ILCs on microbes (and parasites) at mucosal sites other than the intestine has been best studied in the lungs. ILC2s are the dominant ILC subset in the lungs at the steady state, as a consequence of the production of IL-33 and TSLP by the alveolar epithelium [67]. 
197 The production of IL-5 and IL-13 by ILC2s promotes the recruitment of eosinophils, the

198 differentiation of monocyte into M2 (or alternatively activated) macrophages, and the differentiation of $\mathrm{T}$ cells into Th2 cells [68-70]. ILC2s contribute to the resistance to lung parasites, such as Strongyloides venezuelensis [71], Nippostrongylus brasiliensis [72,73], Litomosoides sigmodontis [74], as well as to tissue repair [75]. However, type 2 immunity induced by ILC2s also leads to increased susceptibility to fungal [76,77] and bacterial infection [78], by mechanisms of immunological cross-regulation [4].

Type 2 immunity promoted by ILC2s plays an important role in the repair phase of immune responses, which occurs, for example, after influenza A virus infection through the production of the EGFR ligand amphiregulin [79]. This repair response is nevertheless inhibited by IFN $\gamma$ that is induced by the virus infection [80]. Furthermore, the ILC2-initiated repair responses, induced by virus-induced tissue damage, can lead to exacerbated type 2 responses and, as a consequence, asthma. Such an association, and the mechanisms driving this association, have been reported in the context of infection with rhinovirus [81-83] and respiratory syncytial virus $[84,85]$. Similar pathological consequences are also induced by the fungi Alternaria alternata [86] and Cryptococcus neoformans [87].

ILC3s also play an important role in the lungs in response to bacterial and fungal infections. IL-22 produced by ILC3s is instrumental in lung immunity to Streptococcus pneumoniae [88] and Pseudomonas aeruginosa [89]. Interestingly, neonatal colonization of mice with intestinal bacteria induces the influx of IL-22-producing ILC3s into the lung, which confer life-saving resistance to early infection by Streptococcus pneumoniae [90].

\section{Concluding remarks}

220 We have discussed recent data showing the critical role played by ILC early in the immune 221 responses to pathogens, as these cells can respond promptly to inducer cytokines provided by myeloid and epithelial cells upon infection and injury. Of note, $\mathrm{T}_{\mathrm{RM}}$ cells, as well as particular subsets of invariant $\mathrm{T} \alpha \beta$ or $\mathrm{T} \gamma \delta$ cells, can play similar roles as their activation state alleviates the requirement for antigen-specific TCR activation. The prompt activation of ILCs is also important in response to changes in the symbiotic microbiota, in order to maintain homeostasis.

The current knowledge on the role of ILCs in defense and homeostasis has been inferred form mouse models and association studies in human. It is now possible to design strategies to harness the central role of ILCs in homeostasis, defense and immunoregulation for the prevention and therapy of infectious diseases, and of pathological consequences of 
231 microbiota dysbiosis. It is also possible that novel vaccination strategies benefit from an early 232 manipulation of ILCs, in order to force the response to specific antigens into the type most 233 adapted to fight the pathogen. The manipulation of ILCs may involve the administration of 234 inducer cytokines, or other molecules, yet to be discovered, that specifically activate subsets 235 of ILCs. Another possibility is the isolation of ILC precursors from the blood of patients, and 236 their expansion in vitro into the desired subset before re-administration and induction of type 2371,2 or 3 immune responses. We are still in the early days of ILC biology, but also at the 238 exciting transition phase when clinical applications become possible. 
Table 1

\begin{tabular}{|c|c|c|c|c|c|}
\hline $\begin{array}{l}\text { ILC } \\
\text { type }\end{array}$ & Role & Microbe type & Microbe species & Organ & References \\
\hline \multirow[t]{4}{*}{ ILC1 } & + & Bacteria & Clostridium difficile & Intestine & {$[46]$} \\
\hline & + & Virus & Adenovirus & Liver & {$[44]$} \\
\hline & + & & Mouse hepatitis virus & Liver & {$[45]$} \\
\hline & + & & Cytomegalovirus & Liver & {$[43]$} \\
\hline \multirow[t]{13}{*}{ ILC2 } & - & Bacteria & Streptococcus pneumoniae & Lung & {$[78]$} \\
\hline & - & Virus & Rhinovirus & Lung & [81-83] \\
\hline & - & & Respiratory syncytial virus & Lung & {$[84,85]$} \\
\hline & $+1-$ & & Influenza & Lung & {$[79,80]$} \\
\hline & $+/-$ & Fungi & Cryptococcus neoformans & Lung & {$[76,77,87]$} \\
\hline & - & & Alternaria altnernata & Lung & {$[86]$} \\
\hline & + & Parasites & Trichinella spiralis & Intestine & {$[34]$} \\
\hline & + & & Trichuris muris & Intestine & {$[35]$} \\
\hline & + & & Heligmosomoides polygyrus & Intestine & [32] \\
\hline & + & & Nippostrongylus brasiliensis & Intestine/lung & {$[30,31,72,73]$} \\
\hline & + & & Strongyloides venezuelensis & Intestine/lung & {$[33,71]$} \\
\hline & + & & Litomosoides sigmodontis & Lung & {$[74]$} \\
\hline & + & & Schistosoma haematobium & Blood & {$[36]$} \\
\hline \multirow[t]{15}{*}{ ILC3 } & + & Bacteria & Commensal microbiota & Intestine & {$[15,24,47,49,54,62-64]$} \\
\hline & + & & Citrobacter rodentium & Intestine & {$[18,21-23,50,52,61]$} \\
\hline & + & & Escherichia coli $K 1$ & Intestine & {$[26]$} \\
\hline & + & & $S F B$ & Intestine & {$[55,65]$} \\
\hline & + & & Lactobacilli & Intestine & {$[56]$} \\
\hline & + & & Alcaligenes & Intestine & {$[9,10]$} \\
\hline & $+1-$ & & Salmonella enterica & Intestine & {$[25]$} \\
\hline & $+1-$ & & Salmonella typhimurium & Intestine & {$[29,60]$} \\
\hline & $+1-$ & & Helicobacter typhlonius & Intestine & {$[53]$} \\
\hline & + & & Streptococcus pneumoniae & Lung & {$[88,90]$} \\
\hline & + & & Pseudomonas aeruginosa & Lung & {$[89]$} \\
\hline & + & & Klebsiella pneumoniae & Blood & {$[26]$} \\
\hline & + & Virus & Rotavirus & Intestine & {$[28]$} \\
\hline & + & Fungi & Candida albicans & Lung & [89] \\
\hline & + & Parasites & Toxoplasma gondii & Intestine & [27] \\
\hline
\end{tabular}




\section{Conflict of interests}

244 We declare no conflicts of interests 


\section{References}

[1] Eberl G, Colonna M, Di Santo JP, McKenzie AN. Innate lymphoid cells: a new paradigm in immunology. Science 2015;348:aaa6566.

[2] Serafini N, Vosshenrich CA, Di Santo JP. Transcriptional regulation of innate lymphoid cell fate. Nat Rev Immunol 2015;15:415-28.

[3] Mueller SN, Mackay LK. Tissue-resident memory T cells: local specialists in immune defence. Nat Rev Immunol 2016;16:79-89.

[4] Eberl G. Immunity by equilibrium. Nat Rev Immunol 2016;16:524-32.

[5] Eberl G. A new vision of immunity: homeostasis of the superorganism. Mucosal Immunol 2010;3:450-60.

[6] Proctor DM, Relman DA. The landscape ecology and microbiota of the human nose, mouth, and throat. Cell Host Microbe 2017;21:421-32.

[7] Consortium HMP. Structure, function and diversity of the healthy human microbiome. Nature 2012;486:207-14.

[8] Virgin HW, Wherry EJ, Ahmed R. Redefining chronic viral infection. Cell 2009;138:30-50.

[9] Sonnenberg GF, Monticelli LA, Alenghat T, Fung TC, Hutnick NA, Kunisawa J et al. Innate lymphoid cells promote anatomical containment of lymphoid-resident commensal bacteria. Science 2012;336:1321-5.

[10] Obata T, Goto Y, Kunisawa J, Sato S, Sakamoto M, Setoyama H et al. Indigenous opportunistic bacteria inhabit mammalian gut-associated lymphoid tissues and share a mucosal antibody-mediated symbiosis. Proc Natl Acad Sci U S A 2010;107:7419-24.

[11] Aagaard K, Ma J, Antony KM, Ganu R, Petrosino J, Versalovic J. The placenta harbors a unique microbiome. Sci Transl Med 2014;6:237ra65.

[12] Trinchieri G. Natural killer cells wear different hats: effector cells of innate resistance and regulatory cells of adaptive immunity and of hematopoiesis. Semin Immunol 1995;7:83-8.

[13] Mebius RE, Rennert P, Weissman IL. Developing lymph nodes collect CD4 ${ }^{+} \mathrm{CD}^{-} \mathrm{LTb}^{+}$ cells that can differentiate to APC, NK cells, and follicular cells but not T or B cells. Immunity 1997;7:493-504.

[14] Adachi S, Yoshida H, Kataoka H, Nishikawa S. Three distinctive steps in Peyer's patch formation of murine embryo. Int Immunol 1997;9:507-14.

[15] Bouskra D, Brezillon C, Berard M, Werts C, Varona R, Boneca IG et al. Lymphoid tissue genesis induced by commensals through NOD1 regulates intestinal homeostasis. Nature 2008;456:507-10.

[16] Honda K, Nakano H, Yoshida H, Nishikawa S, Rennert P, Ikuta K et al. Molecular basis for hematopoietic/mesenchymal interaction during initiation of Peyer's patch organogenesis. J Exp Med 2001;193:621-30.

[17] Eberl G, Marmon S, Sunshine MJ, Rennert PD, Choi Y, Littman DR. An essential function for the nuclear receptor ROR $\gamma \mathrm{t}$ in the generation of fetal lymphoid tissue inducer cells. Nat Immunol 2004;5:64-73.

[18] Satoh-Takayama N, Vosshenrich CA, Lesjean-Pottier S, Sawa S, Lochner M, Rattis F et al. Microbial flora drives interleukin 22 production in intestinal NKp46+ cells that provide innate mucosal immune defense. Immunity 2008;29:958-70.

[19] Cella M, Fuchs A, Vermi W, Facchetti F, Otero K, Lennerz JK et al. A human natural killer cell subset provides an innate source of IL-22 for mucosal immunity. Nature 2009;457:722-5.

[20] Luci C, Reynders A, Ivanov, II, Cognet C, Chiche L, Chasson L et al. Influence of the transcription factor RORgammat on the development of NKp46+ cell populations in gut and skin. Nat Immunol 2009;10:75-82. 
[21] Sanos SL, Bui VL, Mortha A, Oberle K, Heners C, Johner C et al. RORgammat and commensal microflora are required for the differentiation of mucosal interleukin 22producing NKp46+ cells. Nat Immunol 2009;10:83-91.

[22] Sonnenberg GF, Monticelli LA, Elloso MM, Fouser LA, Artis D. CD4(+) Lymphoid tissue-inducer cells promote innate immunity in the gut. Immunity 2011;34:122-34.

[23] Guo X, Qiu J, Tu T, Yang X, Deng L, Anders RA et al. Induction of innate lymphoid cell-derived interleukin-22 by the transcription factor STAT3 mediates protection against intestinal infection. Immunity 2014;40:25-39.

[24] Wang Y, Koroleva EP, Kruglov AA, Kuprash DV, Nedospasov SA, Fu YX et al. Lymphotoxin beta receptor signaling in intestinal epithelial cells orchestrates innate immune responses against mucosal bacterial infection. Immunity 2010;32:403-13.

[25] Klose CS, Kiss EA, Schwierzeck V, Ebert K, Hoyler T, d'Hargues Y et al. A T-bet gradient controls the fate and function of CCR6-RORgammat+ innate lymphoid cells. Nature 2013;494:261-5.

[26] Deshmukh HS, Liu Y, Menkiti OR, Mei J, Dai N, O'Leary CE et al. The microbiota regulates neutrophil homeostasis and host resistance to Escherichia coli K1 sepsis in neonatal mice. Nat Med 2014;20:524-30.

[27] Wagage S, Harms Pritchard G, Dawson L, Buza EL, Sonnenberg GF, Hunter CA. The group 3 innate lymphoid cell defect in aryl hydrocarbon receptor deficient mice is associated with $\mathrm{T}$ cell hyperactivation during intestinal infection. PLoS One 2015;10:e0128335.

[28] Hernandez PP, Mahlakoiv T, Yang I, Schwierzeck V, Nguyen N, Guendel F et al. Interferon-lambda and interleukin 22 act synergistically for the induction of interferonstimulated genes and control of rotavirus infection. Nat Immunol 2015;16:698-707.

[29] Lo BC, Gold MJ, Hughes MR, Antignano F, Valdez Y, Zaph C et al. The orphan nuclear receptor ROR alpha and group 3 innate lymphoid cells drive fibrosis in a mouse model of Crohn's disease. Sci Immunol 2016;1:pii: eaaf8864.

[30] Moro K, Yamada T, Tanabe M, Takeuchi T, Ikawa T, Kawamoto H et al. Innate production of $\mathrm{T}(\mathrm{H}) 2$ cytokines by adipose tissue-associated c-Kit $(+) \mathrm{Sca}-1(+)$ lymphoid cells. Nature 2009;463:540-4.

[31] Fallon PG, Ballantyne SJ, Mangan NE, Barlow JL, Dasvarma A, Hewett DR et al. Identification of an interleukin (IL)-25-dependent cell population that provides IL-4, IL5, and IL-13 at the onset of helminth expulsion. J Exp Med 2006;203:1105-16.

[32] Shimokawa C, Kanaya T, Hachisuka M, Ishiwata K, Hisaeda H, Kurashima Y et al. Mast cells are crucial for induction of group 2 innate lymphoid cells and clearance of helminth infections. Immunity 2017;46:863-74 e4.

[33] Mukai K, Karasuyama H, Kabashima K, Kubo M, Galli SJ. Differences in the Importance of Mast Cells, Basophils, IgE, and IgG versus That of CD4(+) T Cells and ILC2 Cells in Primary and Secondary Immunity to Strongyloides venezuelensis. Infect Immun 2017;85:

[34] Angkasekwinai P, Sodthawon W, Jeerawattanawart S, Hansakon A, Pattanapanyasat K, Wang YH. ILC2s activated by IL-25 promote antigen-specific Th2 and Th9 functions that contribute to the control of Trichinella spiralis infection. PLoS One 2017; 12:e0184684.

[35] Spencer SP, Wilhelm C, Yang Q, Hall JA, Bouladoux N, Boyd A et al. Adaptation of innate lymphoid cells to a micronutrient deficiency promotes type 2 barrier immunity. Science 2014;343:432-7.

[36] Nausch N, Appleby LJ, Sparks AM, Midzi N, Mduluza T, Mutapi F. Group 2 innate lymphoid cell proportions are diminished in young helminth infected children and restored by curative anti-helminthic treatment. PLoS Negl Trop Dis 2015;9:e0003627. 
[37] Huang Y, Guo L, Qiu J, Chen X, Hu-Li J, Siebenlist U et al. IL-25-responsive, lineagenegative KLRG1(hi) cells are multipotential 'inflammatory' type 2 innate lymphoid cells. Nat Immunol 2015;16:161-9.

[38] Howitt MR, Lavoie S, Michaud M, Blum AM, Tran SV, Weinstock JV et al. Tuft cells, taste-chemosensory cells, orchestrate parasite type 2 immunity in the gut. Science 2016;351:1329-33.

[39] Gerbe F, Sidot E, Smyth DJ, Ohmoto M, Matsumoto I, Dardalhon V et al. Intestinal epithelial tuft cells initiate type 2 mucosal immunity to helminth parasites. Nature 2016;529:226-30.

[40] von Moltke J, Ji M, Liang HE, Locksley RM. Tuft-cell-derived IL-25 regulates an intestinal ILC2-epithelial response circuit. Nature 2016;529:221-5.

[41] Klose CSN, Mahlakoiv T, Moeller JB, Rankin LC, Flamar AL, Kabata H et al. The neuropeptide neuromedin $U$ stimulates innate lymphoid cells and type 2 inflammation. Nature 2017;549:282-86.

[42] Cardoso V, Chesne J, Ribeiro H, Garcia-Cassani B, Carvalho T, Bouchery T et al. Neuronal regulation of type 2 innate lymphoid cells via neuromedin U. Nature 2017;549:277-81.

[43] Weizman OE, Adams NM, Schuster IS, Krishna C, Pritykin Y, Lau C et al. ILC1 confer early host protection at initial sites of viral infection. Cell 2017;171:795-808 e12.

[44] Krueger PD, Narayanan S, Surette FA, Brown MG, Sung SJ, Hahn YS. Murine liverresident group 1 innate lymphoid cells regulate optimal priming of anti-viral CD8+ T cells. J Leukoc Biol 2017;101:329-38.

[45] Gil-Cruz C, Perez-Shibayama C, Onder L, Chai Q, Cupovic J, Cheng HW et al. Fibroblastic reticular cells regulate intestinal inflammation via IL-15-mediated control of group 1 ILCs. Nat Immunol 2016;17:1388-96.

[46] Abt MC, Lewis BB, Caballero S, Xiong H, Carter RA, Susac B et al. Innate immune defenses mediated by two ILC subsets are critical for protection against acute Clostridium difficile infection. Cell Host Microbe 2015;18:27-37.

[47] Sawa S, Lochner M, Satoh-Takayama N, Dulauroy S, Berard M, Kleinschek M et al. RORgt+ innate lymphoid cells regulate intestinal homeostasis by integrating negative signals from the symbiotic microbiota. Nat Immunol 2011;12:320-26.

[48] Kanamori Y, Ishimaru K, Nanno M, Maki K, Ikuta K, Nariuchi H et al. Identification of novel lymphoid tissues in murine intestinal mucosa where clusters of c-kit ${ }^{+}$IL-7R ${ }^{+}$ Thy $1^{+}$lympho-hemopoietic progenitors develop. J Exp Med 1996;184:1449-59.

[49] Tsuji M, Suzuki K, Kitamura H, Maruya M, Kinoshita K, Ivanov, II et al. Requirement for lymphoid tissue-inducer cells in isolated follicle formation and $\mathrm{T}$ cell-independent immunoglobulin a generation in the gut. Immunity 2008;29:261-71.

[50] Longman RS, Diehl GE, Victorio DA, Huh JR, Galan C, Miraldi ER et al. CX(3)CR1(+) mononuclear phagocytes support colitis-associated innate lymphoid cell production of IL-22. J Exp Med 2014;211:1571-83.

[51] Mortha A, Chudnovskiy A, Hashimoto D, Bogunovic M, Spencer SP, Belkaid Y et al. Microbiota-dependent crosstalk between macrophages and ILC3 promotes intestinal homeostasis. Science 2014;343:1249288.

[52] Satpathy AT, Briseno CG, Lee JS, Ng D, Manieri NA, Kc W et al. Notch2-dependent classical dendritic cells orchestrate intestinal immunity to attaching-and-effacing bacterial pathogens. Nat Immunol 2013;14:937-48.

[53] Powell N, Walker AW, Stolarczyk E, Canavan JB, Gokmen MR, Marks E et al. The transcription factor T-bet regulates intestinal inflammation mediated by interleukin-7 receptor+ innate lymphoid cells. Immunity 2012;37:674-84. 
[54] Atarashi K, Nishimura J, Shima T, Umesaki Y, Yamamoto M, Onoue M et al. ATP drives lamina propria T(H)17 cell differentiation. Nature 2008;455:808-12.

[55] Sano T, Huang W, Hall JA, Yang Y, Chen A, Gavzy SJ et al. An IL-23R/IL-22 circuit regulates epithelial serum amyloid A to promote local effector Th17 responses. Cell 2015;163:381-93.

[56] Nakamoto N, Amiya T, Aoki R, Taniki N, Koda Y, Miyamoto K et al. Commensal lactobacillus controls immune tolerance during acute liver injury in mice. Cell Rep 2017;21:1215-26.

[57] Tumanov AV, Koroleva EP, Guo X, Wang Y, Kruglov A, Nedospasov S et al. Lymphotoxin controls the IL-22 protection pathway in gut innate lymphoid cells during mucosal pathogen challenge. Cell Host Microbe 2011;10:44-53.

[58] Ibiza S, Garcia-Cassani B, Ribeiro H, Carvalho T, Almeida L, Marques R et al. Glialcell-derived neuroregulators control type 3 innate lymphoid cells and gut defence. Nature 2016;535:440-43.

[59] Liang SC, Tan XY, Luxenberg DP, Karim R, Dunussi-Joannopoulos K, Collins M et al. Interleukin (IL)-22 and IL-17 are coexpressed by Th17 cells and cooperatively enhance expression of antimicrobial peptides. J Exp Med 2006;203:2271-9.

[60] Goto Y, Obata T, Kunisawa J, Sato S, Ivanov, II, Lamichhane A et al. Innate lymphoid cells regulate intestinal epithelial cell glycosylation. Science 2014;345:1254009.

[61] Pickard JM, Maurice CF, Kinnebrew MA, Abt MC, Schenten D, Golovkina TV et al. Rapid fucosylation of intestinal epithelium sustains host-commensal symbiosis in sickness. Nature 2014;514:638-41.

[62] Zhang Y, Kim TJ, Wroblewska JA, Tesic V, Upadhyay V, Weichselbaum RR et al. Type 3 innate lymphoid cell-derived lymphotoxin prevents microbiota-dependent inflammation. Cell Mol Immunol 2017;

[63] Kruglov AA, Grivennikov SI, Kuprash DV, Winsauer C, Prepens S, Seleznik GM et al. Nonredundant function of soluble LTalpha3 produced by innate lymphoid cells in intestinal homeostasis. Science 2013;342:1243-6.

[64] Hepworth MR, Monticelli LA, Fung TC, Ziegler CG, Grunberg S, Sinha R et al. Innate lymphoid cells regulate CD4+ T-cell responses to intestinal commensal bacteria. Nature 2013;498:113-7.

[65] Goto Y, Panea C, Nakato G, Cebula A, Lee C, Diez MG et al. Segmented filamentous bacteria antigens presented by intestinal dendritic cells drive mucosal Th17 cell differentiation. Immunity 2014;40:594-607.

[66] Korn LL, Thomas HL, Hubbeling HG, Spencer SP, Sinha R, Simkins HM et al. Conventional CD4+ $\mathrm{T}$ cells regulate IL-22-producing intestinal innate lymphoid cells. Mucosal Immunol 2014;7:1045-57.

[67] McKenzie AN, Spits H, Eberl G. Innate lymphoid cells in inflammation and immunity. Immunity 2014;41:366-74.

[68] Molofsky AB, Nussbaum JC, Liang HE, Van Dyken SJ, Cheng LE, Mohapatra A et al. Innate lymphoid type 2 cells sustain visceral adipose tissue eosinophils and alternatively activated macrophages. J Exp Med 2013;210:535-49.

[69] Nussbaum JC, Van Dyken SJ, von Moltke J, Cheng LE, Mohapatra A, Molofsky AB et al. Type 2 innate lymphoid cells control eosinophil homeostasis. Nature 2013;502:2458.

[70] Halim TY, Steer CA, Matha L, Gold MJ, Martinez-Gonzalez I, McNagny KM et al. Group 2 innate lymphoid cells are critical for the initiation of adaptive T helper 2 cellmediated allergic lung inflammation. Immunity 2014;40:425-35.

[71] Yasuda K, Matsumoto M, Nakanishi K. Importance of both innate immunity and acquired immunity for rapid expulsion of S. venezuelensis. Front Immunol 2014;5:118. 
[72] Bando JK, Nussbaum JC, Liang HE, Locksley RM. Type 2 innate lymphoid cells constitutively express arginase-I in the naive and inflamed lung. J Leukoc Biol 2013;94:877-84.

[73] Bouchery T, Kyle R, Camberis M, Shepherd A, Filbey K, Smith A et al. ILC2s and T cells cooperate to ensure maintenance of M2 macrophages for lung immunity against hookworms. Nature communications 2015;6:6970.

[74] Boyd A, Killoran K, Mitre E, Nutman TB. Pleural cavity type 2 innate lymphoid cells precede Th2 expansion in murine Litomosoides sigmodontis infection. Exp Parasitol 2015;159:118-26.

[75] Turner JE, Morrison PJ, Wilhelm C, Wilson M, Ahlfors H, Renauld JC et al. IL-9mediated survival of type 2 innate lymphoid cells promotes damage control in helminthinduced lung inflammation. J Exp Med 2013;210:2951-65.

[76] Flaczyk A, Duerr CU, Shourian M, Lafferty EI, Fritz JH, Qureshi ST. IL-33 signaling regulates innate and adaptive immunity to Cryptococcus neoformans. J Immunol 2013;191:2503-13.

[77] Piehler D, Grahnert A, Eschke M, Richter T, Kohler G, Stenzel W et al. T1/ST2 promotes $\mathrm{T}$ helper 2 cell activation and polyfunctionality in bronchopulmonary mycosis. Mucosal Immunol 2013;6:405-14.

[78] Saluzzo S, Gorki AD, Rana BMJ, Martins R, Scanlon S, Starkl P et al. First-breathinduced type 2 pathways shape the lung immune environment. Cell Rep 2017;18:1893905.

[79] Monticelli LA, Sonnenberg GF, Abt MC, Alenghat T, Ziegler CG, Doering TA et al. Innate lymphoid cells promote lung-tissue homeostasis after infection with influenza virus. Nat Immunol 2011;12:1045-54.

[80] Califano D, Furuya Y, Roberts S, Avram D, McKenzie ANJ, Metzger DW. IFN-gamma increases susceptibility to influenza A infection through suppression of group II innate lymphoid cells. Mucosal Immunol 2018;11:209-19.

[81] Hong JY, Bentley JK, Chung Y, Lei J, Steenrod JM, Chen Q et al. Neonatal rhinovirus induces mucous metaplasia and airways hyperresponsiveness through IL-25 and type 2 innate lymphoid cells. J Allergy Clin Immunol 2014;134:429-39.

[82] Jackson DJ, Makrinioti H, Rana BM, Shamji BW, Trujillo-Torralbo MB, Footitt J et al. IL-33-dependent type 2 inflammation during rhinovirus-induced asthma exacerbations in vivo. Am J Respir Crit Care Med 2014;190:1373-82.

[83] Han M, Rajput C, Hong JY, Lei J, Hinde JL, Wu Q et al. The innate cytokines IL-25, IL-33, and TSLP cooperate in the induction of type 2 innate lymphoid cell expansion and mucous metaplasia in rhinovirus-infected immature mice. $J$ Immunol 2017;199:1308-18.

[84] Saravia J, You D, Shrestha B, Jaligama S, Siefker D, Lee GI et al. Respiratory Syncytial Virus Disease Is Mediated by Age-Variable IL-33. PLoS Pathog 2015;11:e1005217.

[85] Stier MT, Bloodworth MH, Toki S, Newcomb DC, Goleniewska K, Boyd KL et al. Respiratory syncytial virus infection activates IL-13-producing group 2 innate lymphoid cells through thymic stromal lymphopoietin. J Allergy Clin Immunol 2016;138:814-24 e11.

[86] Stier MT, Zhang J, Goleniewska K, Cephus JY, Rusznak M, Wu L et al. IL-33 promotes the egress of group 2 innate lymphoid cells from the bone marrow. J Exp Med 2018;215:263-81.

[87] Piehler D, Eschke M, Schulze B, Protschka M, Muller U, Grahnert A et al. The IL-33 receptor (ST2) regulates early IL-13 production in fungus-induced allergic airway inflammation. Mucosal Immunol 2016;9:937-49. 
[88] Van Maele L, Carnoy C, Cayet D, Ivanov S, Porte R, Deruy E et al. Activation of type 3 innate lymphoid cells and interleukin 22 secretion in the lungs during Streptococcus pneumoniae infection. J Infect Dis 2014;210:493-503.

[89] Mear JB, Gosset P, Kipnis E, Faure E, Dessein R, Jawhara S et al. Candida albicans airway exposure primes the lung innate immune response against Pseudomonas aeruginosa infection through innate lymphoid cell recruitment and interleukin-22associated mucosal response. Infect Immun 2014;82:306-15.

[90] Gray J, Oehrle K, Worthen G, Alenghat T, Whitsett J, Deshmukh H. Intestinal commensal bacteria mediate lung mucosal immunity and promote resistance of newborn mice to infection. Sci Transl Med 2017;9: pii: eaaf9412. 
507 Legends to figures

508

509 Figure 1. The activation of innate lymphoid cells. The three types of ILCs are promptly

510 activated by distinct types of threats. Such threats are detected by myeloid and non511 hematopoietic cells, which express inducer cytokines (in boxes). In reaction to inducer 512 cytokines, ILCs express effector cytokines that both activate defense mechanisms and 513 regulate immunity.

515 Figure 2. The control of microbiota and pathogens by ILCs. The response of ILCs to 516 symbiotic microbes and pathogens have been extensively described in the intestine and lung, 517 to include bacteria, viruses, fungi and parasites, as well as viruses in the liver. Given their 518 prompt activation, ILCs play a critical role early in the effector response to perturbations in 519 the microbiota and to pathogens, and in the regulation of adaptive immunity. In some cases, 520 however, the reactivity of ILCs contributes to pathology. 
Figure 1

Intracellular threats

(Tumors, viruses and intracellular bacteria)

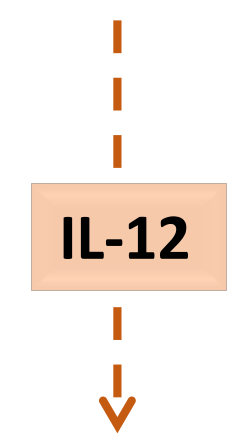

ILC1

T-BET

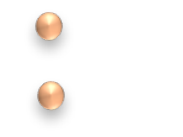

IFNy
Large parasites

(Helminths)

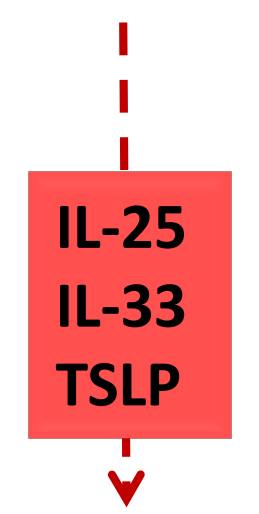

ILC2

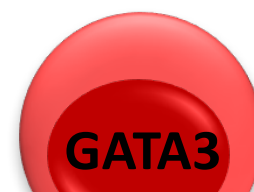

0

-

IL-4

IL-5

IL-13

Areg
Extracellular microbes

(Bacteria, fungi)

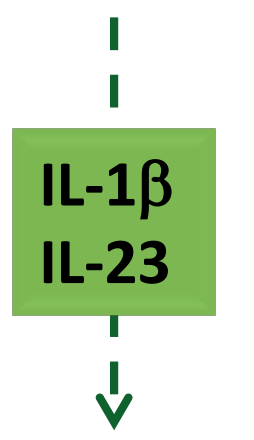

ILC3

RORyt

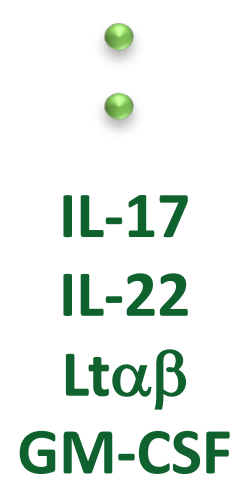




\section{Figure 2}

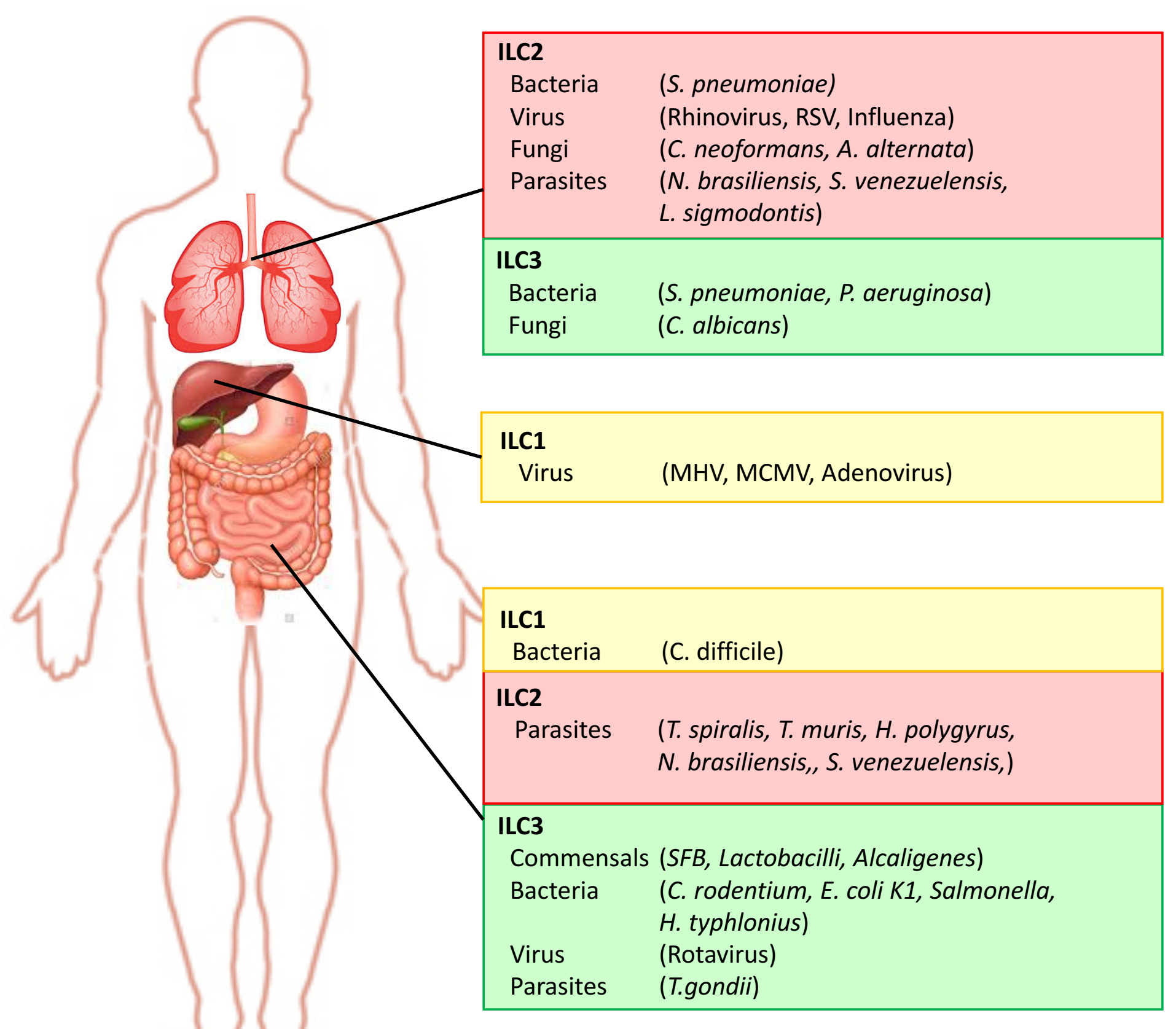

